\title{
REFLEXÕES SOBRE ENTIDADES DE ASSISTÊNCIA SOCIAL E ENTIDADES FECHADAS DE PREVIDÊNCIA PRIVADA ${ }^{1}$
}

\author{
Andrea Nárriman Cezne ${ }^{2}$
}

\section{Resumo:}

O presente trabalho tem por objetivo analisar a questão do tratamento constitucional tributário das entidades de assistência social, especificamente abordando o caso das Entidades Fechadas de Previdência Complementar (EFPC) e a possibilidade de enquadramento no rol de entidades assistenciais. Em relação a essas entidades, conhecidas também como Fundos de Pensão, observa-se que elas eram incluíam na definição de entidade de assistência social para fins de imunidade tributária, por expressa equiparação prevista na Lei n. 6.435 , de 15/07/77. Entretanto, a Constituição Federal de 1988 trouxe consigo uma série de inovações referentes à ordem social, inclusive a separação entre saúde, assistência e previdência social. Além desse fato, as EFPC perderam a equiparação da regulação integral da matéria por duas leis complementares de 2001: a L.C. no 108 e a L.C. 109. O trabalho acompanhou os acórdãos mais relevantes sobre o caso das EFPC, e a definição de novos padrões pelo Supremo Tribunal Federal, culminando com a edição da Súmula 730.

Palavras-chave: Imunidade Tributária das Entidades Assistenciais - Entidades Fechadas de Previdência Complementar (EFPC)

\footnotetext{
${ }^{1}$ Este trabalho realizou-se no contexto da tese de doutoramento da autora, em andamento junto ao Programa de PósGraduação em Direito - PPGD/UFRGS, sob orientação do Prof. Dr. Cezar Saldanha de Souza Júnior.

${ }^{2}$ Doutoranda junto ao Programa de Pós-Graduação em Direito - PPGD/UFRGS. Professora do Centro Universitário Franciscano - UNIFRA.
} 


\section{Introdução}

O conceito de entidades de assistência social no Direito brasileiro, utilizado para a definição da imunidade tributária específica, sofre de problemas estruturais, uma vez que as normas constitucionais que a elas se referiram nunca trataram de definir sua natureza. Várias questões conflituosas prevalecem ainda na doutrina e na jurisprudência, entre elas a questão da possibilidade do enquadramento da Entidades Fechadas de Previdência Complementar (EFPC) como entidades assistenciais para fins de obter a imunidade, sendo uma das maiores polêmicas enfrentadas no assunto.

A imunidade relativa a impostos surgiu na Constituição Federal de $1946^{3}$ e repetiu-se posteriormente, com algumas alterações, nas Cartas Constitucionais de $1967^{4}$ (cuja redação foi modificada pela Emenda Constitucional oo1 de 1969) e de 1988. Atualmente, a redação é a seguinte:

Art. 150. Sem prejuízo de outras garantias asseguradas ao contribuinte, é vedado à União, aos Estados, ao Distrito Federal e aos Municípios:

$\mathrm{VI}$ - instituir impostos sobre:

c) patrimônio, renda ou serviços dos partidos políticos, inclusive suas fundações, das entidades sindicais dos trabalhadores, das instituições de educação e de assistência social, sem fins lucrativos, atendidos os requisitos da lei.

Sobre a definição do que seja essa entidade assistencial coberta pela norma imunizante, e quais os limites dessa imunidade (além dos expressamente previstos pelo $\S 4^{\circ}$ do respectivo artigo), muito se tem escrito e discutido, seja pela doutrina, inclinada a interpretações mais flexíveis e favoráveis ao contribuinte, seja pela jurisprudência oscilante do STF. Quanto a requisitos expressamente previsto no artigo 150, VI, "C", somente se encontra a inexistência de fins lucrativos. Referindo-se aos outros possíveis requisitos, são objeto de acirrada discussão de doutrinadores e do Poder Judiciário, evidenciando-se o conflito em questões limítrofes, como é o caso das entidades aqui em estudo. Observe-se que não há referência expressa às entidades de previdência fechada no artigo acima transcrito.

\footnotetext{
${ }^{3}$ CF/46: Art 31 - A União, aos Estados, ao Distrito Federal e aos Municípios é vedado:

V - lançar impostos sobre: b) templos de qualquer culto bens e serviços de Partidos Políticos, instituições de educação e de assistência social, desde que as suas rendas sejam aplicadas integralmente no País para os respectivos fins;

${ }^{4}$ Art 20 - É vedado à União, aos Estados, ao Distrito Federal e aos Municípios:

III - criar imposto sobre: c) o patrimônio, a, renda ou os serviços de Partidos Políticos e de instituições de educação ou de assistência social, observados os requisitos fixados em lei;
} 
Pode-se definir as Entidades Fechadas de Previdência Complementar, também chamadas de fundos de pensão (do termo inglês pension funds), como organismos constituídos basicamente para fornecer prestações previdenciárias (aposentadoria e pensão) a um grupo determinado ou determinável de pessoas, definido através de uma relação com o patrocinador ou instituidor da entidade, que gera pertinência à EFPC. Nos termos do art. 31 da Lei Complementar 109/01:

Art. 31. As entidades fechadas são aquelas acessíveis, na forma regulamentada pelo órgão regulador e fiscalizador, exclusivamente:

I - aos empregados de uma empresa ou grupo de empresas e aos servidores da União, dos Estados, do Distrito Federal e dos Municípios, entes denominados patrocinadores ${ }^{5}$; e

II - aos associados ou membros de pessoas jurídicas de caráter profissional, classista ou setorial, denominadas instituidores.

A EFPC é financiada através de contribuições dos próprios participantes ${ }^{6}$ e do patrocinadores ${ }^{7}$, em proporções que variam conforme a característica do planos instituídos e de seu custeio, havendo casos em que o custeio cabe totalmente ao patrocinador (embora essa modalidade tenda a extinguir-se, tendo em vista a nova legislação reguladora da matéria). Obviamente, a definição do que sejam essas entidades, do tipo de prestação oferecida e da forma específica de sua constituição sofreu considerável variação no correr do tempo, especialmente no que se refere às espécies de prestações. Empréstimos, assistência médico-hospitalar, farmacêutica, odontológica, prestação suplementar de alimentação, educação e habitação, eram prestações ordinariamente oferecidas nas várias espécies de fundos de pensão e caixas de assistência (MARTINEZ, 2002, p. 242). Apesar dessas modificações, algumas características comuns podem ser elencadas (MARTINEZ, 2002, p. 36-37): a facultatividade (referindo-se à manifestação de vontade, ainda que mínima, no ingresso

\footnotetext{
${ }^{5}$ Conforme a Lei Complementar no 109/01:

Art. 12. Os planos de benefícios de entidades fechadas poderão ser instituídos por patrocinadores e instituidores, observado o disposto no art. 31 desta Lei Complementar.

Art. 13. A formalização da condição de patrocinador ou instituidor de um plano de benefício dar-se-á mediante convênio de adesão a ser celebrado entre o patrocinador ou instituidor e a entidade fechada, em relação a cada plano de benefícios por esta administrado e executado, mediante prévia autorização do órgão regulador e fiscalizador, conforme regulamentação do Poder Executivo.

${ }^{6}$ (LC 109/01) Art. 8o Para efeito desta Lei Complementar, considera-se:

I - participante, a pessoa física que aderir aos planos de benefícios; e

II - assistido, o participante ou seu beneficiário em gozo de benefício de prestação continuada.

${ }^{7}$ Podendo haver um único patrocinador ou vários, conforme se vê do Art. 34. da mesma lei: As entidades fechadas podem ser qualificadas da seguinte forma, além de outras que possam ser definidas pelo órgão regulador e fiscalizador:

$\begin{array}{ll}\text { (..) II - de acordo com seus patrocinadores ou instituidores: } & \text { a) singulares, quando estiverem vinculadas }\end{array}$ a apenas um patrocinador ou instituidor; e b) multipatrocinadas, quando congregarem mais de um patrocinador ou instituidor.
} 
nesses planos), a acessoriedade (também chamada de supletividade, em referência ao papel considerado auxiliar da Previdência Pública), o fato de ser poupança individual (caracterizando-se como um esforço individual no acúmulo de recursos, resultando posteriormente em benefícios previdenciários próprios), ser atividade exercida por delegação estatal (em vista do interesse público envolvido, submetendo-se a estrito controle governamental), a solidariedade (por constituir-se em atividade de seguro social, com aspectos mutualistas). MARTINEZ (2002) conceitua previdência complementar da seguinte forma:

(...) cuida-se de um conjunto de operações econômico-financeiras, cálculos atuariais, práticas contábeis, e normas jurídicas, empreendidas no âmbito particular da sociedade, ainda inserida no Direito Privado, subsidiária do esforço estatal, de adesão espontânea, propiciando benefícios adicionais ou assemelhados, mediante recursos exclusivos do protegido (aberta e associativa), ou divididos ou encargos entre o empregado e o empregador, ou apenas de um destes (fechada). (p.37)

\section{Histórico das Entidades Fechadas de Previdência Complementar}

Historicamente, registra-se a criação de Montepios e Caixas de Previdência desde a época do Império. Entre esses, pode-se destacar o MONGERAL (Montepio Geral de Economia dos Servidores do Estado), criado em 1835 e que pode ser considerado como a primeira entidade de Previdência Complementar brasileira - pelas características de facultatividade e mutualismo. Adiciona-se a esse o surgimento da Caixa de Previdência dos funcionários do Banco do Brasil S.A. - PREVI, em 16/04/1904 (o maior fundo de pensão brasileiro em 2002). A Caixa de Pensão dos Funcionários do Casa da Moeda foi objeto do Decreto no 9284, de 30.12. 1911. Ressalte-se que até o ano de 1923, com a criação da Previdência Pública para os ferroviários e alguns servidores civis e militares, não se pode falar em Previdência Complementar, por inexistência da básica. $O$ que havia eram planos mutualistas, que continuaram a existir mesmo após a Lei Elói Chaves (MARTINEZ, 2002, p. 30).

Em termos normativos, a matéria somente iniciou a ser regulada através da Lei no 6.435, de 15 de julho de 1977, cujo objetivo era tratar das chamadas "entidades de previdência privada". Embora haja registro de legislações anteriores cujo objetivo era criar entidades específicas de natureza semelhante, somente houve uma regulação da matéria genericamente pela referida lei (RODRIGUES, Flávio Martins, 2003, p. 178) As entidades de previdência privada eram definidas, nos termos do Art $1^{\circ}$, como "as que têm por objeto 
instituir planos privados de concessão de pecúlios ou de rendas, de benefícios complementares ou assemelhados aos da Previdência Social, mediante contribuição de seus participantes, dos respectivos empregadores ou de ambos." Tratou a lei de diferenciar as entidades de previdência privada em duas espécies principais: entidades de previdência fechadas e entidades de previdência aberta, essas últimas com fins lucrativos, em que a pertinência é definida essencialmente pelo pagamento das respectivas contribuições ao plano escolhido (critério econômico).

As Constituições anteriores à de 1988 pouco ou nada preocuparam-se em regular claramente o campo da Previdência e Assistência Social. Observando-se os artigos esparsos referentes ao assunto ${ }^{8}$, verifica-se o tratamento pontual e assistemático da matéria nas cartas anteriores, que somente foi ratificado na Constituição Federal de 1988. Registre-se que não existia sequer referência específica à previdência complementar nesses diplomas anteriores (RODRIGUES, 2003, p.178)

\section{Padrão Regulatório das Entidades Fechadas de Previdência Complementar a partir da Constituição Federal de 1988}

A Constituição Federal de 1988 dedicou todo o Capítulo II do Título da Ordem Social à Seguridade Social, subdividindo-a em três grandes campos: saúde, previdência social e assistência social. A previdência complementar é expressamente prevista através do art. 202, com a seguinte redação:

Art. 202. O regime de previdência privada, de caráter complementar e organizado de forma autônoma em relação ao regime geral de previdência social, será facultativo, baseado na constituição de reservas que garantam o benefício contratado, e regulado por lei complementar.

\footnotetext{
${ }^{8}$ Dispositivos sobre previdência e assistência social nas Constituições anteriores:

CF/34: Art 121 § 1ํ- A legislação do trabalho observará os seguintes preceitos, além de outros que colimem melhorar as condições do trabalhador: $\mathrm{h}$ ) assistência médica e sanitária ao trabalhador e à gestante, assegurando a esta descanso antes e depois do parto, sem prejuízo do salário e do emprego, e instituição de previdência, mediante contribuição igual da União, do empregador e do empregado, a favor da velhice, da invalidez, da maternidade e nos casos de acidentes de trabalho ou de morte;

CF/37: Art 137 - A legislação do trabalho observará, além de outros, os seguintes preceitos: I) assistência médica e higiênica ao trabalhador e à gestante, assegurado a esta, sem prejuízo do salário, um período de repouso antes e depois do parto;

Art 157 - A legislação do trabalho e a da previdência social obedecerão nos seguintes preceitos, além de outros que visem a melhoria da condição dos trabalhadores: XIV - assistência sanitária, inclusive hospitalar e médica preventiva, ao trabalhador e à gestante; XV - assistência aos desempregados; XVI - previdência, mediante contribuição da União, do empregador e do empregado, em favor da maternidade e contra as conseqüências da doença, da velhice, da invalidez e da morte;

CF/67: Art 158 - A Constituição assegura aos trabalhadores os seguintes direitos, além de outros que, nos termos da lei, visem à melhoria, de sua condição social:

$\mathrm{XVI}$ - previdência social, mediante contribuição da União, do empregador e do empregado, para segurodesemprego, proteção da maternidade e, nos casos de doença, velhice, invalidez e morte;
} 
Visando implementar o mandamento constitucional de que lei complementar regulasse 0 assunto, posteriormente a Previdência Complementar foi totalmente regulamentada pelas Leis Complementares $108^{9}$ e 109, ambas de 29 de maio de 2001. A Lei Complementar 109/01 revogou totalmente a Lei ํ 6.435, de 15 de julho de 1977, já que tratou de todo o campo da previdência complementar. Estabeleceu novos parâmetros às entidades de previdência complementar abertas e fechadas, inclusive no tocante à espécie de prestação a ser oferecida ao assistido.

A questão que pertence à seara das entidades assistenciais é: seriam as entidades de previdência complementar fechadas entidades assistenciais? Surge a indagação por não haver anteriormente distinção legislativa clara no tratamento de previdência e assistência social, e mais do que isso, a própria Lei 6435/77 previa expressamente a equiparação das EFPC às entidades assistenciais, em seu art. 39 , § $3^{\circ}$ :

\begin{abstract}
As entidades fechadas terão como finalidade básica a execução e operação de planos de benefícios para os quais tenham autorização específica, segundo normas gerais e técnicas aprovadas pelo órgão normativo do Ministério da Previdência e Assistência Social.

$\S 3$ o As entidades fechadas são consideradas instituições de assistência social, para os efeitos da letra c do item II do artigo 19 da Constituição.
\end{abstract}

Uma observação interessante que pode ser feita sobre esse dispositivo legal é a seguinte: se houve a necessidade de equiparação, significa que as entidades de previdência privada não eram consideradas como tal (TEIXEIRA, 2001).

Posteriormente, o dispositivo teria sido revogado pelos Decreto-lei n. 2.065 , de $19 / 10 / 83$, que teve a sua validade contestada. Segundo seus detratores, por se tratar de um Decreto-lei ele não poderia ter retirado um benefício fiscal que somente poderia ser regulamentado através de lei complementar (por se tratar de uma imunidade tributária, mesmo que seja por equiparação da Lei 6435/77). A contrario sensu, pode-se argumentar que a referida lei teria na verdade concedido uma isenção às entidades de previdência fechada através da equiparação às entidades assistenciais, isenção que portanto poderia ser revogada através de uma norma de igual hierarquia. ${ }^{10}$

Entretanto, a partir da Lei Complementar o 109, não somente é inexistente qualquer referência à equiparação às entidades de assistência social, como também há

\footnotetext{
${ }^{9}$ A referida lei é específica, e dispõe somente sobre a relação entre a União, os Estados, o Distrito Federal e os Municípios, suas autarquias, fundações, sociedades de economia mista e outras entidades públicas e suas respectivas entidades fechadas de previdência complementar.
} 
previsão expressa vedando a EFPC o patrocínio de quaisquer prestações além dos previdenciárias, abrangendo essa proibição serviços e prestações de cunho assistencial. Conforme a redação dos artigos 32 e 76 da referida lei:

Art. 32. As entidades fechadas têm como objeto a administração e execução de planos de benefícios de natureza previdenciária.

Parágrafo único. É vedada às entidades fechadas a prestação de quaisquer serviços que não estejam no âmbito de seu objeto, observado o disposto no art. 76.

Art. 76. As entidades fechadas que, na data da publicação desta Lei Complementar, prestarem a seus participantes e assistidos serviços assistenciais à saúde poderão continuar a fazê-lo, desde que seja estabelecido um custeio específico para os planos assistenciais e que a sua contabilização e o seu patrimônio sejam mantidos em separado em relação ao plano previdenciário.

$\S 10$ Os programas assistenciais de natureza financeira deverão ser extintos a partir da data de publicação desta Lei Complementar, permanecendo em vigência, até o seu termo, apenas os compromissos já firmados.

Portanto, não somente as EFPC não tem mais a equiparação legal a entidades assistenciais, como também passaram a ser expressamente proibidas de prestarem serviços dessa natureza, por se incluírem em campo diverso do previdenciário e infringirem as normas de equilíbrio financeiro e atuarial das entidades. ${ }^{11}$ Toda e qualquer prestação deve ter a fonte de custeio especificada, dentro dos referidos padrões. Através desta alteração legislativa, operou-se uma modificação profunda na própria natureza das EFPC, conforme ressalta MARTINEZ (2002, p. 89-90).

\section{O tratamento da Assistência Social na Constituição Federal de 1988 e seus reflexos na questão das EFPC}

Além das questões atinentes às entidades de previdência complementar, ressaltase na Carta de 1988 como novidade o tratamento específico que recebeu a Assistência Social. A Seguridade Social passa a definir a grande área, subdividida em três campos

\footnotetext{
${ }^{10}$ Comentando a revogação do equiparação pelo Decreto-lei 2065, de 26.10.83, Ricardo Lobo Torres (1999, p. 259) ressalta a controvérsia na doutrina, chegando mesmo alguns tribunais federais a declararem inconstitucional o referido decreto-lei.

${ }^{11}$ Vide $\circ \S 2^{\circ}$ do art. 76, ao definir programas assistenciais: "Consideram-se programas assistenciais de natureza financeira, para os efeitos desta Lei Complementar, aqueles em que o rendimento situa-se abaixo da taxa mínima atuarial do respectivo plano de benefícios." A manutenção do nível de contribuição necessário (equilíbrio financeiro-atuarial) está expresso em regras de custeio, entre elas o art. 18: "O plano de custeio, com periodicidade mínima anual, estabelecerá o nível de contribuição necessário à constituição das reservas garantidoras de benefícios, fundos, provisões e à cobertura das demais despesas, em conformidade com os critérios fixados pelo órgão regulador e fiscalizador. Também percebe-se a atuação desse princípio na necessidade de custeio específico para a assistência à saúde (fim do caput do art. 76)
} 
separados - saúde, previdência social e assistência social. Essa última, conforme a dicção do artigo 203, será prestada a quem dela necessitar, independente de contribuição. Colocam-se aí dois requisitos relevantes para a definição constitucional atual de assistência social: atendimento aos hipossuficientes e inexistência de contrapartida por parte do beneficiário do atendimento. Dessa forma, a conformação atual da assistência social não permite que haja contribuição daquele que recebe a prestação assistencial, para que ela possa classificar-se como tal. Obviamente, as entidades podem oferecer serviços sem contraprestação aos necessitados (considerando-se nesse caso como serviços assistenciais) que são parcela do grupo atendido, cobrando de outros para poder realizar suas atividades (desde que os serviços assistenciais sejam o objetivo institucional e significativos). Mas a inexistência de contraprestação, ou seja, a gratuidade, surge como ônus para que a atividade seja considerada assistencial.

Verifica-se aí uma das maiores incompatibilidades com o regime das entidades de previdência complementar, na sua atual conformação. Enquanto na atividade assistencial não pode haver contraprestação, na atividade das EFPC a contraprestação anterior é essencial ao sistema. Não se admite a prestação previdenciária sem o custeio correspondente do participante, seja sozinho (no caso das entidades abertas) seja acompanhado pelo patrocinador, nas entidades fechadas. Apesar de ainda existirem EFPC que são financiadas somente ou em grande parte pelos instituidores, é certo que desaparecerão frente à necessidade de adequação à LC 109/01. Passaram essas entidades a serem exceções em um sistema no qual a regra são contraprestações do participante e do patrocinador.

Apesar desse novo quadro normativo das EFPC, a doutrina mantém-se atrelada aos padrões formatados antes da CF/88. Ao defender a inclusão das entidades de previdência complementar como entidades assistenciais, invocam em sua maior parte precedentes do STF anteriores à CF. Quanto aos requisitos da lei necessários para o enquadramento no art. 150, VI, "c", os doutrinadores aceitam somente aqueles previstos pela Constituição Federal no próprio artigo (inexistência de fins lucrativos) e os requisitos expressos no Código Tributário Nacional (Lei ㄲ5172, de 25/10/1966), em seu artigo $14^{12}$,

\footnotetext{
${ }^{12}$ Redação do art. 14 do CTN: O disposto na alínea $c$ do inciso IV do art. $9^{\circ}$ é subordinado à observância dos seguintes requisitos pelas entidades nele referidas: I- não distribuírem qualquer parcela de seu patrimônio ou de suas rendas, a qualquer título; II - aplicarem integralmente, no País, os seus recursos na manutenção dos seus objetivos institucionais; III - manterem escrituração de suas receitas e despesas em livros revestidos de formalidades capazes de assegurar sua exatidão.
} 
já que formalmente a lei necessária para regular a matéria seria complementar ${ }^{13}$ e o CTN tem hierarquia de lei complementar. Não concorda grande parte da doutrina com a incidência do art. 203 sobre a definição de entidade assistencial, propugnando que os artigos 203 e 204 refeririam-se somente à assistência social estatal, e não ao campo privado. Como exemplos dessa argumentação, citar-se-iam os Votos dos Ministros Marco Aurélio e Sepúlveda Pertence no caso CERES ${ }^{14}$.

No voto do Min. Marco Aurélio (que reproduz seu voto no RE no 219.435-6/MG), argumenta este que não caberia interpretar a assistência social nos moldes do art. 203 da $\mathrm{CF}$, e que entendimento contrário implica a total inutilidade do preceito (do art. 150, VI, "C") já que a seguridade oficial decorre da atuação da autarquia, resultando a imunidade do disposto não na alínea "c", mas na alínea "a" do inciso VI do artigo 150 da Carta em vigor, regra também inserta na Constituição anterior (alínea 'a' do inciso III do artigo 19). Logo, a imunidade da alínea 'c', relativamente às instituições de assistência social, alcança pessoas jurídicas de direito privado. Não possuindo fins lucrativos, e seguindo os moldes colocados no art. 14 do CTN, a instituição cumpriria os requisitos referidos pela norma constitucional (p. 500-501 do ref. processo).

O Voto de Sepúlveda Pertence cita os seguintes argumentos a favor da imunidade: a necessidade de restrição da aplicação do art. 203 ao campo da assistência social pública, sob pena de interferir no sentido do art 150, VI, c Também refere ao mesmo raciocínio do voto do Min. Marco Aurélio no RE 219.435. O art. 203 não trataria de toda a assistência social, mas se aplicaria somente ao domínio "o da assistência social à população verdadeiramente carente - de regra, excluída do mercado formal de trabalho e, pois, do âmbito de benefícios previdenciários, mediante contribuição - , a ser custeada, por isso, mediante recursos orçamentários, afora fontes voluntárias eventuais, como ficou explicitado na disposição constitucional subseqüente" [cita o art. 204] (P. 536 do processo) Trazendo os argumentos de Alberto Xavier ${ }^{15}$, aduz que não é possível aplicarse às entidades assistenciais privadas o regime da assistência social pública. Baseia-se em três diretrizes o argumento comparativo: a facultatividade da previdência e assistência privadas e o exercício obrigatório da assistência e da previdência públicas; a liberalidade

\footnotetext{
${ }^{13}$ A questão da espécie de lei necessária (ordinária ou complementar) para regulamentar as imunidades tributárias referentes às entidades assistenciais, tanto a do art. 150 , VI, 'c', quanto a do art. $195, \S 7^{\circ}$ da $\mathrm{CF} / 88$ ainda não é pacífica na doutrina e principalmente na jurisprudência (como exemplo, a discussão realizada na ADIn $2028 \mathrm{MC} / \mathrm{DF}$ ). Expõe-se aqui a corrente que defende a exigência de lei complementar, a parti da aplicação do art. 146, II da CF/88.

${ }^{14}$ STF: RE no 202.700-6, DJ 01.03.2002 Rel: Min. Maurício Correa, Data do acórdão: 08/11/2001 Tribunal Pleno

${ }^{15}$ XAVIER, Alberto. As Entidades Fechadas de Previdência Privada. Revista Dialética de Direito Tributário, no 52/19 (apud RE no 202.700-6, p. 536)
} 
dos atos da assistência e da previdência privada, enquanto a assistência e previdência públicas são baseadas em tributos; a contraposição entre previdência e assistência social se basearia em um dado regime positivo, não na essência do conceito em causa.

Outro argumento, criado por Ives Gandra da Silva Martins e seguido por muitos doutrinadores ${ }^{16}$, seria a existência de uma assistência social lato sensu e uma assistência social stricto sensu na Constituição Federal. Cite-se o próprio autor em suas palavras (MARTINS, 2003, p. 72):

Creio, portanto, não ter me enganado, quando, em 1990, ao comentar o artigo 150, VI, letra 'a' da Constituição, formulei a teoria dos conceitos de assistência social "lato sensu" e "stricto sensu", aquele rigorosamente abrangente da seguridade social com as três áreas interligadas, e este, reduzido, exclusivamente, às ações estritas de assistência social, independentemente de assistência na área de saúde e previdência.

A assistência social lato sensu consistiria em quaisquer atividades ou prestações que resultassem num melhoramento das condições de vida da população, relacionada a necessidades relevantes como saúde, educação, etc. Esse conceito permitiria a inclusão da previdência social como uma de suas formas. A assistência social stricto sensu seria aquela prevista no art. 203, apenas uma forma específica de assistência fornecida aos necessitados, sem contraprestação. Segundo essa corrente doutrinária, não poderia a interpretação do art. 150, VI, "c", ser restrita ao conteúdo do art. 203, mas teria que corresponder à definição mais ampla. $O$ argumento da não utilização do artigo 203 e 204 da CF/88 pode ser embasado na existência de norma constitucional específica (o art. 150, VI, "c"), devendo os artigos 203 e 204 serem auxiliares na interpretação, conforme Odim B. FERREIRA:

O preceito do art. 150, VI, c, deveria ser apenas aclarado pelos artigos $201 \mathrm{e}$ 203 da Constituição da República, sem se perder de vista que a norma de regência do caso se encontra no primeiro dos dispositivos. Do modo como empregado, o argumento inverteu as funções dos termos da equação sistemática. Ao invés de ter seu sentido esclarecido pelos demais dispositivos mas sempre mantendo a qualidade de norma de regência da matéria, o artigo $150, \mathrm{VI}, \mathrm{c}$, teve seu sentido alterado pelas duas outras que não dizem respeito primordialmente ao problema tributário. Em virtude disso, é que, com todas as vênias, endossar o ponto de vista analisado redundaria em atribuir ao art. 150 em sentido talvez compatível com os dois outros artigos da Constituição, mas que certamente não se reconduz ao próprio conteúdo.

Ademais, como acentuou MÜLLER, a transição do primeiro modelo de interpretação sistemática (dispositivos diversos da norma de regência do caso servem apenas ao seu esclarecimento) para o segundo (normas diversas da de regência do caso passam a codeterminar a solução do problema) somente

\footnotetext{
${ }^{16}$ Alguns exemplos: Francisco de Assis Alves (Imunidade Tributária. In: Imunidades Tributárias. Coord. Ives Gandra da Silva Martins. São Paulo: Editora Revista dos Tribunais: Centro de Extensão Universitária, 1998 - p. 268-315); Daniele Russi Campos (Imunidade Tributária das Entidades Fechadas de Previdência Privada. In: Revista Tributária e de Finanças Públicas. N. 46. São Paulo: Revista dos Tribunais, set-out 2002. Ano 10. P. 105-125.
} 
pode acontecer caso se demonstre que a implicação dessas outras normas no desate da controvérsia decorre da necessidade imposta pelos demais elementos de concretização jurídica, como o gramatical, histórico, teleológico, etc. Ora, se a obscuridade desta exposição não tiver sido absoluta, poder-se-á dizer que todos os elementos de concretização do artigo 150, VI, c, não recomendam - antes, desaconselham, o emprego das normas trazidas pela interpretação sistemática analisada. A codeterminação do problema pelas normas do capítulo da seguridade social seria recomendável se decorresse da necessidade revelada pelo dispositivo constitucional regente da imunidade.

Ocorre que, dentre outros tantos argumentos em contrário, já se viu que o art. 150, VI, c, contém em si mesmo, o critério econômico das entidades imunes, que é o não agirem no afã do lucro. Assim, não parece acertado buscar outro dado econômico em dispositivos constitucionais alheios à imunidade. Nada indica a necessidade de co-implicar as normas de seguridade social, sobretudo porque, a norma tributária aponta para sentido diverso da seguridade social. (2001, p. 140-141)

Observe-se que, de acordo com o autor, a inexistência de fins lucrativos seria critério suficiente para preencher os requisitos do art. 150 VI, "C". Mas esse argumento é inaceitável, pois não se confunde a atividade de assistência social somente com a inexistência de fins lucrativos, obviamente sendo esse último requisito básico para que uma instituição seja assistencial. A definição do que seja assistência social não se encontra implícita no referido artigo que trata da imunidade em si, e é absolutamente necessária à definição das instituições em pauta. Evidentemente, havendo um conceito constitucional delimitado e explícito de assistência social, não poderá o intérprete do artigo 150, VI, "c", desprezá-lo somente porque se encontra em outra parte da Constituição.

O mesmo autor, Odim B. Ferreira, propugna a existência de benefícios tributários diferenciados na Constituição Federal, relacionados a essas atividades específicas. In verbis:

Quando a Constituição desejou conferir certas vantagens apenas às pessoas absolutamente altruístas, ela as denominou 'entidades beneficentes de assistência social' (art. 195, $\$ 7^{\circ}$ ). No momento em que desejou impor ao Estado não apenas uma perda de receitas, mas impor-lhe a prestação gratuita de serviços - os de assistência aos empregados referidos -, o constituinte restringiu os interessados. Desse sacrifício adicional da coletividade, encarnada no Estado, apenas são dignos os que não tenham nenhum interesse nos benefícios proporcionados pela pessoa jurídica. Para tratamento ainda mais benigno do que a imunidade, exige-se mais alto grau de comprometimento humanitário.

Há gradação muito nítida no tratamento tributário das pessoas jurídicas envolvidas na atividade de assistência social. Quem explora a atividade de assistência social segundo as regras da livre iniciativa- obter lucro -, pagará imposto, como qualquer outro agente econômico. Aquele que desenvolver o mesmo projeto, sem o intuito de lucro, embora no âmbito mais restrito do grupo de contribuintes, terá a imunidade dos impostos do art. 150, VI, c, da Constituição Federal. Por fim, a 'entidade beneficente', que presta assistência social de maneira inteiramente altruística, gozará do favor fiscal mencionado, 
além de ficar exonerada de contribuir para o custeio do sistema público de seguridade social, em razão de ter empregados. (2001, p. 114)

Não se questiona especificamente a argumentação apresentada, mas apenas aquilo que se aproveita dela ao tratar das EFPC, na análise de sua pertinência ou não ao campo do art. 150, VI, "C", da CF/88. A maioria da doutrina não aceita a aplicação do art. 203 às entidades de assistência social beneficiadas pela imunidade do art. 150, VI, c. Além disso, propugna-se que a própria Constituição permitiria essa interpretação da assistência social lato sensu, a partir da redação do artigo 149, $\S 1^{017}$. In verbis: "Os Estados, o Distrito Federal e os Municípios poderão instituir contribuição, cobrada de seus servidores, para o custeio, em benefício destes, de sistemas de previdência e assistência social." Tratando de sistemas de previdência e assistência social, supostamente teria corroborado o conceito mais amplo de assistência social, englobando também o campo previdenciário. De acordo com Mizabel DERZI (1999, p. 324):

Seja como for, é evidente que não há um sentido inequívoco incontestável entre a redação do art. 149 , que permite a cobrança de tributo próprio para custear os sistemas de previdência e assistência social estadual e municipal, e a redação do art. 203. Esse último claramente estabelece como único critério para a prestação da assistência social o da necessidade, independentemente do pagamento de contribuição. Não é que o artigo referido proíba a cobrança. É que, como o critério é o da necessidade, portanto o da carência de recursos ou incapacidade dos assistidos, o pressuposto lógico e coerente é que não haja cobrança de contribuição. Entretanto, o art. 149 fala genericamente em previdência e assistência social, em favor dos servidores públicos, permitindo, para isso, cobrar deles uma contribuição específica. Dessa forma, não temos uma garantia de sentido unívoco da utilização da expressão assistência social, utilizada no Capítulo da Tributação.

Entretanto, esses argumentos podem ser refutados a partir da análise da conformação tanto da Assistência Social, como da Previdência Complementar na CF/88, bem como da legislação posterior que passou a regular respectivamente cada uma delas: a Lei Complementar 109/01 e a Lei Orgânica da Assistência Social (a Lei 8742, de 07/12/1993). A separação entre previdência e assistência social passa a ser clara a partir da Carta de 1988. Outrosssim, não haveria motivo para regulação em seções diversas, cada qual com princípios próprios. Ressaltam-se entre esses como fatores discriminatórios a necessidade de contraprestação e o público-alvo de cada uma delas, restrito aos participantes e assistidos na previdência, e direcionado a quem dela precisar,

\footnotetext{
${ }^{17}$ Em sua redação anterior à EC №41, de 19/12/2003. Com a redação atual, desaparece a referência à assistência social no artigo e a base do argumento apresentado. In verbis: "Os Estados, o Distrito Federal e os Municípios instituirão contribuição, cobrada de seus servidores, para o custeio, em benefício destes, do regime previdenciário de que trata o art. 40, cuja alíquota não será inferior à da contribuição dos servidores titulares de cargos efetivos da União."
} 
no caso da assistência social. Segundo TEIXEIRA (2001, p. 01), ao comentar a questão da imunidade tributária perante o Art. 150, VI, "C":

\begin{abstract}
Do texto transcrito se infere que a Constituição, ao dispor sobre a imunidade tributária, em momento algum determinou que a imunidade abrangeria as entidades de previdência social, ao contrário, apenar fez referência às instituições de assistência social. Assim, enquadrar a previdência social dentro do conceito de assistência social seria, no mínimo, violar a própria Constituição, pois (..) previdência social e assistência são coisas distintas, e essa distinção é feita, em sua essência, pela própria Lei Magna nos arts. 194 e seguintes. Além disso, termos idênticos contidos nas normas constitucionais não podem, sob pena de quebrar a uniformidade do sistema jurídico, ser interpretados com um sentido quando postos num determinado capítulo (no caso, o capítulo correspondente à seguridade social) e com outro, quando constantes de capítulo diferente (no caso, o capítulo correspondente ao sistema tributário nacional).
\end{abstract}

A diferenciação acentua-se a partir da Lei Complementar n 109/01,conforme já exposto acima, pois essa prevê o fim de prestações assistenciais. Portanto, 0 reconhecimento da imunidade assistencial para as EFPC somente poderá dar-se a entidades que ainda mantenham serviços assistenciais e mais do que isso: nas quais não haja contraprestação correspondente do beneficiário, somente do patrocinador.

A inexistência da contraprestação, ou seja, a gratuidade na prestação de serviços assistenciais pelas EFPC (baseada no art. 203), tem sido decisiva, diferenciando as respectivas entidades, e possibilitando ainda o reconhecimento do benefício imunitório. Essa é a tendência que tem se manifestado nos últimos acórdãos do Supremo Tribunal Federal.

\title{
5. Breve Análise da Jurisprudência do Supremo Tribunal Federal Relativa às Entidades Assistenciais e sua Relação com as Entidades Fechadas de Previdência Privada
}

Analisar a evolução da jurisprudência do STF em busca de padrões para a determinação se as entidades de previdência privada deveriam ser consideradas entidades assistenciais para os fins do art. 150, VI, "C" é uma tarefa frustante pelas constantes oscilações no posicionamento, que ora focalizava uma determinada espécie de requisito, ora outra. A própria concepção dos requisitos mudou desde os primeiros acórdãos. De acordo com Ricardo Lobo Torres (1999, p. 260), inicialmente "O Supremo Tribunal Federal deu ao problema da imunidade das entidades de previdência privada interpretação magnânima e ampliativa, que só recentemente passou a ser colocada em termos razoáveis." 
A análise de Odim B. Ferreira ${ }^{18}$ sobre a jurisprudência do STF no referido assunto é uma das mais profundas que se tem notícia na doutrina, e passa a ser aqui utilizada para dar a perspectiva histórica do julgamento do tema pela nossa Corte Suprema.

Inicialmente, refere o autor que a análise dos julgamentos pelo STF teve como fundamento teórico a obra de Leopoldo Braga, que traz três requisitos que devem ser cumpridos pelas instituições de assistência social para que se caracterizassem como tal: A) Fim público institucional; B) Gratuidade e ausência de intuito lucrativo; e C) Generalidade na prestação de serviços ou na distribuição de utilidades e serviços. A análise da jurisprudência permite dizer que são utilizados simultaneamente dois ou três requisitos (com ênfase maior em um ou outro) ou individualmente esses requisitos, sem um padrão estabelecido em todo o período de julgados estudado.

Estudando cada um dos requisitos, o autor trata primeiramente da questão da generalidade (p. 147). Inicialmente, entidades que não fossem abertas ao público em geral tinham sua imunidade simplesmente negada. Somente eram consideradas assistenciais aquelas voltadas a atender às necessidades de todas as pessoas (obviamente, seguindo os objetivos para os quais tenha sido inicialmente determinada, ou seja, atender especificamente crianças, ou idosos, etc), e aquelas com beneficiário limitados ou limitáveis ficavam de fora da imunidade. Somente a partir do RE 70.834 - o Caso da Fundação Ruben Berta, a orientação do STF mudou, inaugurando-se a $2^{\mathrm{a}}$ fase da jurisprudência do STF. De acordo com o mesmo (p. 148):

\begin{abstract}
Numa segunda fase, percebe-se um momento de transição entre as orientações: 0 Tribunal não deseja romper com as decisões até ali tomadas, apagando o critério da generalidade, mas também não as quer endossar para o futuro. A saída encontrada é não negar o critério e, sim, emprestar-lhe novo conteúdo. (..) Para tanto, depois de admitir que 'a recorrente é uma Fundação de caráter assistencial e visa ao amparo e ao benefício dos que a compõem, o relator [do RE 70.834] Min. Adalício Nogueira afirma: a argumentação (..) de que a recorrente é 'uma entidade assistencial fechada, isto é, os seus objetos institucionais são destinados, exclusivamente, aos seus funcionários, dela Fundação e aos da Varig, não pode ser acolhida nos termos estritos em que foi posta. Onde a lei mão distingue, não é lícito ao intérprete distinguir.
\end{abstract}

Considerou-se que o atendimento de um círculo de beneficiários de amplitude indefinida - o fato da entidade ser aberta aos que integram ou viessem a integrar o

\footnotetext{
${ }^{18}$ Esta análise foi feita em um artigo, "Imunidade Tributária das Entidades de Previdência Fechada", In: Revista dos Tribunais: Cadernos de Direito Tributário e Finanças Públicas. São Paulo: Revista dos Tribunais, 1995. Abril-junho 1995, N. 11, o primeiro de uma série de três artigos, e posteriormente repetida em seu livro, no qual apresenta o estudo completo: FERREIRA, Odim Brandão. A Imunidade Tributária das Entidades de Previdência Fechada - Uma análise sob a perspectiva da Metodologia Jurídica. Porto Alegre: Sergio Antonio Fabris, 2001. Foi utilizado aqui o citado artigo.
} 
quadro de funcionários - serviria para preencher o requisito da generalidade. Na mesma seqüência seguiram-se outros julgamentos do mesmo teor: RE 74.792 (o caso da Real Sociedade Espanhola de Beneficiência/ Sanatório Espanhol), no qual coexistiam o atendimento gratuito aos seus associados, também atendimento gratuito a um determinado número de pessoas pobres e atendimento pago ao público em geral. $\mathrm{O} R E$ 89.012 (Serviço Social da Indústria do Papel, Papelão e Cortiças do Estado de São Paulo) tratou do assunto da mesma forma, ressaltando o cumprimento do art. 14 do CTN e o auxílio ao Estado na prestação de serviços assistenciais.

O abandono total do critério da generalidade pelo STF, representando um rompimento com todo o período anterior, deu-se somente através do caso da Fundação DURATEX (RE 108.796/ Rel. Min. Carlos Madeira), no qual a referida foi considerada assistencial por outros fatores (inexistência de manutenção pelos beneficiários e não ter fins lucrativos), considerando-se irrelevante a questão da generalidade. De acordo com a ementa, "A natureza pública da instituição não provém da generalidade de seus participantes, mas dos fins sociais a que atende" (apud FERREIRA, 1995, p. 149). No mesmo sentido, o caso da REFER- Fundação Rede Ferroviária de Seguridade Social (AgRgAg 120.744, rel Min. Francisco Rezek). Conclui-se sobre a análise dos julgados tratando do critério da generalidade que o STF passou por três fases. A primeira delas, de exigência absoluta desse requisito; a segunda fase, de uma exigência mais abrandada do requisito, no qual "a generalidade estaria satisfeita, mesmo quando o círculo dos atendidos fosse constituído por um número restrito de pessoas, definido por meio de outro vínculo jurídico - o trabalhar numa empresa ou o pertencer a certa categoria, ao qual novas pessoas poderiam aderir."(FERREIRA, 195, p. 150) Na segunda fase, o STF reluta em desautorizar os precedentes do próprio tribunal, tentando dar uma nova interpretação ao critério da generalidade. Através dessa flexibilização, houve na verdade uma progressiva abolição do mesmo critério, que somente explicitou-se em uma última fase dos julgados. O problema da generalidade, segundo o autor, é que ela se constitui em um conceito absoluto: ou é aplicável ou não é.

A questão da aplicação do critério da gratuidade e sua conceituação constitui-se como uma das mais polêmicas do assunto. A oscilação dos julgados nesse quesito é constante. Os primeiros acórdãos que tratam da gratuidade propugnam que não é necessário que a prestação seja fornecida gratuitamente. Desse forma, no RE 58.691 (rel. Min. Evandro Lins e Silva), tratando de sociedade educacional, o relator determina que 
não há necessidade de que essa ministre o ensino gratuito totalmente. No julgamento da Real Sociedade Espanhola de Beneficiência (RE 74.792) também referiu-se a questão da gratuidade, concluindo o relator, Min. Djaci Falcão, que a cobrança não infere na conceituação da sociedade como entidade sem fins lucrativos. In verbis:

\begin{abstract}
Como salientou a agravante nas razões de f. 61 , não é a gratuidade da prestação ou do serviço, que lhe oferece a característica da assistência social, por isso que hospitais, mantidos pelos poderes públicos, cobram diárias, de que é exemplo o Hospital dos Servidores Municipais nessa Capital, enquanto outros como o Hospital Getúlio Vargas cobram prestações de seus serviços. Realmente, não seria possível manterem-se as entidades de assistência social, se não lhes fosse permitido cobrar das pessoas que podem pagar e que recorrem a seus serviços (apud FERREIRA, 1995, p. 151).
\end{abstract}

Desta forma, a cobrança não descaracterizaria a sociedade como assistencial, desde que a renda obtida fosse revertida em favor dos objetivos institucionais. Entretanto, logo após encontra-se precedente em sentido inverso, considerando que a cobrança de "jóias e contribuições mensais" dos associados retiraria seu caráter assistencial (RE 63.411 - caso da Associação Beneficente dos Servidores do Departamento Autônomo das Estradas de Rodagem). Posteriormente, definiu-se a necessidade que a cobrança realizada não advenha dos próprios beneficiários - no RE 89.012, o Min. Moreira Alves definiu que o fato da entidade receber recursos de empresas não the retiraria a finalidade social, importando o fato da contribuição não advir dos beneficiários dos serviços de assistência, pois aí não haveria gratuidade (apud FERREIRA, 1995, p. 152). Através do texto do autor (p. 152 e 153), percebem-se oscilações posteriores entre essas duas posições que podem ser demonstradas pela análise dos acórdãos, sucessivamente contraditórios: a favor da gratuidade, proibindo a entidade de receber contribuição de seus beneficiários: RE 108.796, Ag Rg Ag 120.744 e Re 108.120. Pregando a inexigibilidade da gratuidade, o RE 108.737, em que o STF admite que as entidades possam cobrar e obter lucro, desde que esse não seja distribuído entre seus associados (FERREIRA, 1995, p. 153). No mesmo sentido, o RE 116.188. Posteriormente, ao tratar de entidades de previdência fechada, retornou o assunto da gratuidade à baila, no RE 136.321. Conforme consignou o Min. Octavio Gallotti na ementa do acórdão: "Sendo mantida por expressiva contribuição dos empregados, ao lado da satisfeita pelos patrocinadores, não the assiste o direito ao reconhecimento da imunidade tributária, prevista no art. 19, III, c, da Constituição de 1967, visto não se caracterizar, então, como instituição de assistência social."(apud FERREIRA, p. 154) 


\section{O Tratamento Contemporâneo do Supremo Tribunal Federal Relativo às Entidades Fechadas de Previdência Complementar - Acórdãos Paradigmáticos}

O questionamento sobre a gratuidade e generalidade dos serviços prestados retorna através da jurisprudência contemporânea sobre o assunto. Em um julgamento histórico, o caso CERES - Fundação de Seguridade Social dos Sistemas Embrapa e Embrater, definiu um novo padrão em relação aos julgados posteriores referentes à Entidades Fechadas de Previdência Complementar, e sua decisão apoiou-se na existência de cobrança de contribuições dos filiados ao sistema, e nas modificações conceituais realizadas na área de Seguridade Social a partir da Constituição Federal de 1988. Analisando-se o acórdão referido observa-se que existiam dois grandes grupos, um a favor da continuidade dos conceitos anteriores e reconhecimento sucessivo da imunidade, e outro grupo contra o deferimento da imunidade, levando em conta os fatores modificados na relações internas da Ordem Social, na CF/88, mas também retoma argumentos anteriormente trabalhados pelo STF nos julgados tratando do tema, como a questão da gratuidade (que aparentemente estava pacificado). Desta forma, deve-se analisar a situação concreta do acórdão, a fim de entender os argumentos que basearam a decisão do indeferimento da imunidade.

Ementa: RE no 202.700-6 DJ 01.03.2002 Data do acórdão: 08/11/2001

Tribunal Pleno

Rel: Min. Maurício Correa

Recorrente: Distrito Federal Advogado: PGDF - Manoel Cesar Neto

Recorrido: CERES - Fundação de Seguridade Social dos Sistemas Embrapa e Embrater

Advogado: Luiz Carlos Bettiol

Advogados: Antônio Villas Boas Teixeira de Carvalho e outros

Advogado: José Antônio Blanco Césperes

Ementa: RECURSO EXTRAORDINÀRIO. CONSTITUCIONAL. PREVIDÊNCIA PRIVADA. IMUNIDADE TRIBUTÁRIA. INEXISTÊNCIA

1. Entidade fechada de previdência privada. Concessão de benefícios aos filiados mediante recolhimento das contribuições pactuadas. Imunidade tributária. Inexistência, dada a ausência das características de universalidade e generalidade da prestação, próprias dos órgãos de assistência social.

2. As instituições de assistência social, que trazem incito em suas finalidades a observância ao princípio da universalidade, da generalidade e concede benefícios a toda coletividade, independentemente de contraprestação, não se confundem e não podem ser comparadas com as entidades fechadas de previdência privada que, em decorrência da relação contratual firmada, apenas contempla uma categoria específica, ficando o gozo dos benefícios previstos em seu estatuto social dependente do recolhimento das contribuições avençadas, conditio sine quae non para a respectiva integração no sistema.

Recurso extraordinário conhecido e provido.

Acórdão: Vistos, relatados e discutidos estes autos, acordam os Ministros do Supremo Tribunal Federal, em sessão plenária, na conformidade da ata do julgamento e das notas taquigráficas, por maioria de votos, conhecer e dar provimento ao recurso extraordinário interposto pelo Distrito Federal.

Brasília, 08 de novembro de 2001.Presidente: Marco Aurélio. 
O relatório, sinteticamente, traz os seguintes fatos: a Fundação de Seguridade Social dos Sistemas Embrapa e Embrater - CERES, impetrou mandado de segurança contra ato do Diretor do Departamento da Receita da Secretaria do Governo do Distrito Federal para se desonerar do pagamento do IPTU relativo ao ano de 1992. Argumentou que sendo entidade privada de assistência social, estariam vinculados seus fundos à complementação de benefícios dos seus filiados. Desta forma, não seria devida a cobrança do imposto, em face do disposto no art. 150, VI, c e $9^{\circ}, \mathrm{IV}$, "c" e 14, incisos I a III, do CTN. Sustentou que a Lei 6435/77 "definiu as entidades fechadas como complementares do sistema oficia de previdência e assistência social, e por isso mesmo, para atingir os objetivos visados, colabora com a ação estatal, restando claro que a cobrança da exação é inexigível em face da imunidade constitucional." (p. 489) Houve recurso para o Tribunal de Justiça do Distrito Federal, que o proveu, com base na inexistência de fins lucrativos e fins sociais atendidos, a reconhecendo com entidade de assistência social. Ingressou então o DF com recurso especial e extraordinário, sendo este conhecido e provido.

Quanto aos argumentos utilizados no recurso, o DF aduz que há violação do art. 150, VI, c, por não poderem ser consideradas as entidades de previdência privada entidades assistenciais. As entidades assistenciais teriam como característica a prestação de serviços assistenciais a pessoas carentes(necessidade e universalidade), independentemente do recolhimento de contribuições (gratuidade). A mera associação de pessoas reunidas para determinados objetivos, mantidas para 0 trato de interesses particulares de seus filiados, não pode ser considerada como prestadora de assistência s. O recorrente aduz que a previsão é que somente os beneficiários que pagarem poderão usufruir dos benefícios - o não pagamento de parcelas traz como conseqüência o cancelamento da inscrição do segurado, a exclusão do quadro de sócios e a perda do direito à assistência ao filiado e aos seus dependentes. Não bastaria que a entidade cumprisse os requisitos do art. 14 , antes de tudo teria que se tratar de entidade de assistência social. Não seria este o caso porque a entidade somente fornece contraprestações mediante pagamento mensal, "sem realizar atendimento de caráter estritamente social, como o de assistência gratuita a pessoas necessitadas (RE no 108.120-1, relator Ministro Sidney Sanches, in RTJ 125/750) (p. 492). Como último argumento do recurso, a existência de imunidade não se justificaria, já que a entidade somente favoreceria uma categoria específica, sem a devida contraprestação social. 
O voto do relator Maurício Corrêa foi no sentido da restrição da imunidade, utilizando de vasta argumentação. Ressalte-se que o Ministro Sydney Sanches acompanhou o voto do Ministro Relator. Não bastaria que a entidade não tivesse fins lucrativos - deveria observar os requisitos do CTN e a restrição do $\S 4^{\circ}$ do art. 150 do CTN. O Ministro Relator conheceu do Recurso Extraordinário e the deu provimento. A restrição contida nessa norma constitucional aduziria que somente os bens diretamente ligados à realização dos objetivos sociais estariam cobertos pela imunidade, o que não seria o caso de imóveis alugados, que não serviriam diretamente a esses objetivos. Ainda que os requisitos acima fossem satisfeitos, a entidade identificada com de previdência privada não estaria ao abrigo do dispositivo constitucional aduzido, visto que a imunidade somente foi concedida às entidades de assistência social, sem fins lucrativos. Não seriam equivalentes os dois termos (assistência e previdência) visto que se o fossem não haveria razão para que o constituinte as tratasse de forma distinta no art. 194 da CF/88. Também refere-se aos art. 199, $\S 1^{\circ}, 201$ e 203 da CF/88. A diferenciação constitucionalmente prevista concentrar-se-ia na forma de financiamento (contribuições na previdência) e universalidade do atendimento (a assistência social seria dirigida à toda coletividade). Conforme o insigne ministro:

\begin{abstract}
"Vê-se, pois, que a assistência à saúde não é ônus da sociedade isoladamente e sim dever do Estado. A iniciativa privada não pode ser compelida a assistir `a saúde ou a complementar a previdência social sem a devida contraprestação. Por isso, se as entidades privadas se dispuserem a conferir aos seus filiados benefícios previdenciários complementares e os contratados assumiram a obrigação de pagar por isso, o exercício dessa faculdade mão lhes assegura o direito à imunidade tributária constitucional, outorgada pelo legislador apenas às entidades que prestam assistência social, independentemente de contribuição à seguridade social (CF, artigo 203), como estímulo ao altruísmo dos seus instituidores." P. 496
\end{abstract}

As entidades fechadas de previdência privada não poderiam ser comparadas a entidades de assistência social, visto que conferem seus benefícios unicamente aos filiados, desde que estes recolham as contribuições avençadas, a contrario sensu das entidades assistenciais, que devem possuir o caráter de universalidade no atendimento. Por fim, o relator observa que a entidade, além dos benefícios complementares de aposentadoria, auxílio-reclusão e abonos, ainda faculta a seus associados empréstimos pessoais e financiamentos imobiliários. Entretanto, ressalta-se que quem não recolhe a contribuição à Fundação é sumamente eliminado de seus quadros de beneficiário. Assim:

Por isso o caráter meramente contratual da relação jurídica entre a entidade e os seus participantes, o que indica a ausência do requisito da assistência necessária à utilização do favor constitucional: enquanto a assistência social do Estado, em 
atenção ao princípio da universalidade e da generalidade, destina-se a toda a coletividade, independentemente de contraprestação, a entidade de previdência privada apenas contempla uma categoria específica, ficando o gozo dos benefícios previstos em seu estatuto social dependente do pagamento da devida retribuição, que é "conditio sine quae non" para a respectiva integração no sistema." (p. 498)

Conhecendo e dando provimento ao recurso, encontram-se os Ministros Mauricio Correa, Carlos Velloso, Celso de Mello e Sydney Sanches. A favor da imunidade e não conhecendo do recurso temos os Ministros Marco Aurélio, IImar Galvão, Sepúlveda Pertence e Néri da Silveira. A Ministra Ellen Gracie votou também contra o pedido de imunidade, após ter pedido vistas para exame do processo.

Argumentando a favor da imunidade da EFPC, o Min. Marco Aurélio inicialmente refere-se totalmente a seu voto no RE no 219.435-6/MG. A favor da concessão, traz os seguintes argumentos: bastaria cumprir os requisitos do art. 150, VI, 'c' da CF/88 e do art. 14 do CTN para ser concedida a imunidade. Não caberia interpretar a assistência social nos moldes do art. 203 da CF. De acordo com o referido voto:

"Entendimento contrário implica a total inutilidade do preceito. É que a seguridade
oficial decorre da atuação da autarquia e, portanto, de pessoa jurídica da
administração indireta, resultando a imunidade do disposto não na alínea "c", mas
na alínea "a" do inciso VI do artigo 150 da Carta em vigor, regra também inserta na
Constituição anterior (alínea 'a' do inciso III do artigo 19). Logo, cumpre assentar a
premissa de que a imunidade da alínea 'c', relativamente às instituições de
assistência social, alcança pessoas jurídicas de direito privado. A recorrente
enquadra-se nessa categoria, porque constituída com o objetivo de prestar
assistência social aos empregados do BEMGE, não possuindo fins lucrativos,
conforme registrado no acórdão recorrido, estando coberta pela previsão inserta
no artigo 14 do Código Tributário Nacional" (p. 500-501)

Cita também a previsão do $\S 3^{\circ}$ do artigo 39 da Lei $6435 / 77$, que trata as entidades de previdência privada considerando-as como entidades de assistência social. Desta forma, não caberia perquirir da gratuidade dos serviços - não importa a fonte dos recursos, desde que a entidade seja sem fins lucrativos.

O voto do Min. Sepúlveda Pertence também traz argumentos a favor da imunidade. Primeiramente, a restrição da aplicação do art. 203 ao campo da assistência social pública, sob pena de interferir no sentido do art 150, VI, c. Cita também o voto do Min. Marco Aurélio no RE 219.435, trazendo novamente a idéia de que a assistência social do 203 é aquela prestada pela autarquia estatal e portanto, a imunidade devida para a entidade de seguridade oficial, por se tratar de autarquia, é a recíproca (letra "a"). Ressalta que o requisito da gratuidade total não se aplica nem às entidades públicas, conforme o art 149. $O$ art. 203 não trataria, portanto, de toda a assistência social, mas se 
aplica somente ao domínio "o da assistência social à população verdadeiramente carente

- de regra, excluída do mercado formal de trabalho e, pois, do âmbito de benefícios previdenciários, mediante contribuição - , a ser custeada, por isso, mediante recursos orçamentários, afora fontes voluntárias eventuais, como ficou explicitado na disposição constitucional subseqüente (cita o art. 204)." (P. 536 do processo) Aduz aos argumentos de Alberto Xavier, aduz que não é possível aplicar-se às entidades assistenciais privadas o regime da assistência social pública. Baseia-se em três diretrizes o argumento comparativo: a facultatividade da previdência/ assistência privadas e o exercício obrigatório da assistência/previdência públicas; a liberalidade dos atos da assistência/previdência privada, enquanto a assistência/previdência pública; a são baseadas em tributos; a contraposição entre previdência e assistência social se basearia em um dado regime positivo, não na essência do conceito em causa Traz à baila o argumento da gradação entre várias definições de assistência social, presente em Odim B. Ferreira (apud p.538 e 539):

"Há na verdade uma gradação muito nítida no tratamento tributário das pessoas
jurídicas envolvidas na atividade de assistência social. Quem explora a atividade
de assistência social segundo as regras da livre iniciativa - obter lucro - pagará
imposto, como qualquer outro agente econômico. Aquele que desenvolver o
mesmo projeto, sem o intuito de lucro, mas restrito a um certo grupo de
interessados, que contribuam para a persecução da finalidade, terá a imunidade
de impostos do art. $150, \mathrm{VI}$, C, da Constituição Federal. Por fim, a 'entidade
beneficente', que presta assistência social de maneira absolutamente altruística,
gozará do favor fiscal do parágrafo anterior [ $\$ 7^{\circ}$ do art. 195] e, além disso, ficará
exonerada de contribuir mesmo para o custeio do sistema público de seguridade
social, em razão de ter empregados. Esta tese se comprova com o auxílio do art.
204 , I, da Constituição da República, que faz, também, claramente a distinção
entre 'entidades beneficentes e de assistência social'."

O voto do Ministro Celso de Melo para deferir o recurso e afastar a imunidade refere-se tanto à separação clara entre os campos da Assistência, Previdência e Saúde a partir da $\mathrm{CF} / 88$, quanto à necessidade de atendimento do critério da generalidade e da gratuidade. Observe-se inicialmente a primeira questão, referente à separação entre as áreas da Seguridade Social:

Não se pode perder de perspectiva, bem por isso - e tal como enfatizado nos votos proferidos pelos eminentes Ministros MAURícIO CORRÊA e CARLOS VELLOSO - que a Constituição da República claramente distinguiu entre as noções e as finalidades inerentes à previdência e à assistência sociais, especialmente quando dispôs que os planos previdenciários, sempre dependentes de contribuição e sujeitos a critérios que preservem o equilíbrio financeiro e atuarial, atenderão à cobertura dos eventos referentes às doenças, à invalidez, à morte e à idade avançada (CF, art. 201, caput e inciso I) (..) p. 554 
Termina 0 voto ressaltando a distinção entre assistência social pública e assistência social privada (citando o Ministro Maurício Corrêa): "enquanto a assistência social do Estado, em atenção ao princípio da universalidade e da generalidade, destina-se a toda coletividade, independentemente de contraprestação, a entidade de previdência privada apenas contempla uma categoria específica, ficando, o gozo dos benefícios previstos em seu estatuto social, dependente do pagamento da devida retribuição, que é 'conditio sine qua non' para a respectiva integração no sistema." (p. 558-559 do acórdão)

Após um pedido de vistas, o Ministro Néri da Silveira exara seu voto não conhecendo do recurso e portanto, concedendo a imunidade à CERES no caso específico. Inicia ressaltando o tratamento da questão em seções separadas (III e IV) relativamente à previdência e assistência social.

\begin{abstract}
"Nota distintiva, no ponto, das entidades fechadas de previdência privada é o caráter contratual de sua operacionalidade. Com efeito, os benefícios deferidos a seus associador pressupõem recolham contribuições antes ajustadas. Não cabe confundi-las com instituição de assistência social, que, independentemente de contribuições (CF, art. 203), presta os respectivos serviços 'a quem dela necessitar', na realização dos objetivos enumerados no mesmo artigo. As entidades fechadas de previdência privada não possuem, destarte, o sentido de universalidade de atendimento, qual sucede, em princípio, com as instituições de assistência social, assim como as prevê o art. 204, I, da Lei Magna (..)" p. 570.
\end{abstract}

Acentua-se a necessidade de participação da população na formulação de políticas sociais, bem como a integração de setores da sociedade na assistência social. Passa posteriormente a analisar a questão da imunidade, concluindo pela aplicação do art. 14 do CTN, e que a entidade pode ser considerada como assistencial.

Após o voto de Néri da Silveira, passou a haver empate. A Min. Ellen Gracie, que havia se abstido de votar por não ter assistido ao julgamento, pediu vista do processo ( $p$. 576). Em seu voto, reconsiderando a posição que adotara no TRF da $4^{a}$ Região, passa a considerar que a entidade de previdência privada não pode enquadrar-se nos requisitos do Art. 150, VI, "c". Utiliza como fundamento os argumentos do Min. Octavio Gallotti, no RE 136.332 (DJ de 25-6-93):

\footnotetext{
"Admito que, apenas sob a égide da Constituição de 1988, veio a desabrochar plenamente a distinção entre as espécies da 'previdência' e da 'assistência', ramos diferenciados da 'seguridade social'. Veja-se, no Título VIII ('Da Ordem Social'), o Capítulo II, denominado 'Da Seguridade Social' e dividido em Seções, das quais as duas últimas tratam, respectivamente, 'Da Previdência Social' (Seção III) e 'Da Assistência Social' (Seção IV). Nesse novo quadro, bem delineado, a previdência é destinada aos segurados ou contribuintes (art. 201). Ao passo que a assistência, custeada por recursos orçamentários, dirige-se, independentemente de contribuição, 'a quem possa dela necessitar' (art. 203). Penso, todavia, que antes de ter vindo tornar-se solar essa diferenciação, impunha-se ela conceitualmente, a despeito de respeitáveis opiniões em contrário (...)
} 
A Constituição de 1967 já inscrevia, no inciso XVI do art. 165, uma noção suficientemente particularizada de 'previdência social', que não coincide, a meu ver, com o pressuposto da imunidade tributária outorgada pelo art. 19, III, c, às instituições de assistência social. Assim sucede, pelo menos quando, como aqui, a prestação previdenciária (aposentadoria ou pensão) decorre da contribuição do segurado (somada à do empregador), o que me faz retornar ao segundo ponto do roteiro traçado para o exame da questão: o da exigência de não ser a entidade mantida com a contribuição dos beneficiários (RE 108.796, Relator o Ministro CARLOS MADEIRA, $2^{\mathrm{a}}$ Turma, secundada pelo RE 115.970 , relatado pelo Ministro MOREIRA ALVES, $2^{\mathrm{a}}$ Turma, ambos precedidos pelos acórdãos a que se reporta a decisão recorrida)." P. 579-580

A ministra ressalta o relacionamento nitidamente contratual, sinalagmático, que existe entre a instituição e seus participantes, "pautada por contribuições obrigatórias (Estatuto art. 13) com exclusão automática dos que interrompam estes aportes."(p. 580) Reportando-se ao voto do Min. Celso de Mello, ressalta como identificadores das entidades assistenciais a finalidade de ordem pública, a gratuidade, a ausência de intuito lucrativo e a generalidade na prestação de serviços (no caso das EFPC, restrito o atendimento aos associados, em seu próprio benefício). Ressalta que a participação do empregador na formação do capital não afeta o caráter contratual das relações.

Da análise do acórdão do caso da CERES, conclui-se que houve 0 reconhecimento do STF a respeito da questão da separação entre os campos da Assistência, Previdência e Saúde na Carta de 1988, separação essa instrumentalizada posteriormente pela legislação reguladora do setor, haja vista a Lei Complementar 109/01, cujas disposições coadunam-se com essa separação. Também voltou a ressaltarse o aspecto da gratuidade, através da interpretação da norma constitucional do Art. 203, e há uma tendência de ser exigida a generalidade na prestação do serviço para se caracterizar a entidade como assistencial. Conforme já exposto, essa decisão tornou-se paradigmático, modelando toda uma série de acórdãos posteriores.

Posteriormente, o STF aparentemente mudou seu posicionamento novamente, ao reconhecer presente a imunidade no caso da CONSHELL -Sociedade de Previdência Privada, conforme se pode analisar pela ementa do acórdão abaixo transcrito:

RE 259756 / RJ - RIO DE JANEIRO Relator(a): Min. MARCO AURÉLIO

Julgamento: 28/11/2001 Órgão Julgador: Tribunal Pleno Publicação: DJ DATA-29-08-2003 PP-00021 EMENT VOL-02121-17 PP-03493

Partes: RECTE. : UNIÃO FEDERAL ADVDO. : PFN - PAULO JERONYMO DE OLIVEIRA

RECDA. : COMSHELL-SOCIEDADE DE PREVIDÊNCIA PRIVADA ADVDOS. : ILÍDIO DA COSTA LEANDRO E OUTROS

Ementa: IMUNIDADE - ENTIDADE FECHADA DE PREVIDÊNCIA PRIVADA. Na dicção da ilustrada maioria, entendimento em relação ao qual guardo reservas, o fato de mostrar-se onerosa a participação dos beneficiários do plano de previdência privada afasta a imunidade prevista na alínea "c" do inciso VI do 
artigo 150 da Constituição Federal. Incide o dispositivo constitucional, quando os beneficiários não contribuem e a mantenedora arca com todos os ônus. Consenso unânime do Plenário, sem o voto do ministro Nelson Jobim, sobre a impossibilidade, no caso, da incidência de impostos, ante a configuração da assistência social Observação: Votação: unânime.

Entretanto, a situação concreta diferenciou-se da situação do caso CERES acima exposto. A peculiaridade existente é a inexistência de contribuição por parte dos beneficiários, sendo o custeio responsabilidade exclusiva da mantenedora. Isso fez com que o próprio Min. Marco Aurélio (relator do processo) levasse a julgamento a questão em destaque, ressaltando o caso concreto como excepcional. Conforme a "Explicação" do ref. Ministro Relator (RE 259.756-2 - RJ):

\begin{abstract}
"A Corte concluiu que as entidades de previdência privada, assistenciais, não gozam de imunidade tributária. Assim procedeu no caso concreto, em que havia a contribuição patronal e a do empregado. Na espécie em exame, ocorre justamente o contrário - só temos o patrocínio pelo tomador do serviço. Esse aspecto foi por mim colocado em segundo plano no voto que proferi, pois o entendi irrelevante. $A$ meu ver, aqueles que votaram pelo afastamento da imunidade consideraram 0 caráter oneroso do benefício. Por isso, estou trazendo o caso à Mesa (..) A situação, portanto, é mais favorável do que a enfrentada pelo Plenário - quando este se dividiu e deliberou inexistir a imunidade - e merece destaque, repito, porque a contribuição não é bilateral. Temos assistência que podemos dizer 'totalmente gratuita'.
\end{abstract}

Destaque-se que o requisito preponderante para configurar a imunidade da entidade foi a inexistência de contraprestação aos beneficiários, sendo o custeio responsabilidade exclusiva da mantenedora. Portanto, a exigência da prestação gratuita dos serviços aos beneficiários, ou ao menos a grande parte deles, estabelece-se em ambos os julgados. A contradição á aparente - o que se visa é estabelecer limites concretos entre duas espécies diferentes de entidades. 


\section{Conclusões}

1- A definição de entidades de assistência social para fins da imunidade tributária do art. 150, VI, 'c', ainda é problemática, tendo em vista a dificuldade na delimitação de seu campo em função da falta de definição do que sejam entidades assistenciais no próprio artigo. Nesse quadro, a questão específica das EFPC e seu enquadramento na referida imunidade surge como uma das mais polêmicas, em razão das alterações normativas sofridas e das oscilações jurisprudenciais.

2- A CF/88 reservou tratamento específico à matéria da Seguridade Social no Capítulo II de seu Título VIII (Da Ordem Social), diferenciando-se nesse aspecto das Constituições anteriores, que trataram genericamente e de forma assistemática da previdência e assistência social. A CF/88 diferenciou claramente os campos da saúde, previdência e assistência social, tratando-as em seções diversas do mesmo capítulo. A previdência complementar recebeu tratamento próprio através dos dispositivos do artigo 202. Nesse mesmo artigo, previu-se a criação de leis complementares para regular a matéria no campo das EFPC, tanto no campo das entidades patrocinadas por entes públicos como por entes privados, regra corporificada através das Leis Complementares 108 e 109, ambas de 29 de maio de 2001.

3- As Leis Complementares 108/01 e 109/01 regularam inteiramente a matéria pertinente à previdência complementar, revogando a legislação anteriormente pertinente, a Lei 6435/77. Essa lei ordinária previa a equiparação das EFPC às entidades assistenciais para fins de imunidade, em seu artigo 39, §3 $3^{\circ}$ A LC no 109 não somente não repete o referido dispositivo, como também proíbe expressamente a instituição de benefícios de caráter assistencial, que não seja contraprestacional, através de seu art. 76. Dessa forma, as EFPC terão necessariamente que se adaptar progressivamente às normas elencadas na legislação complementar, prevendo que todas as prestações e serviços serão custeados com a participação dos beneficiários.

4- A atividade assistencial, a partir dos parâmetros expostos no art. 203 da CF/88, deverá se prestada a quem dela necessitar, independente de contribuição. Percebe-se aí o conflito estabelecido entre as duas atividades: enquanto a gratuidade do atendimento aos hipossuficientes é requisito básico na assistência 
social, no caso do sistema de previdência complementar a contraprestação é essencial ao sistema. Depreende-se isso não somente do expressamente previsto na LC 109/01, mas da própria dicção do art. 202 da CF/88. Portanto, de acordo com a sistemática adotada pela $\mathrm{CF} / 88$, não somente a assistência social e a previdência complementar foram reguladas separadamente, como também na questão específica da necessidade de contraprestação do beneficiário, são totalmente incompatíveis uma com a outra.

5- A doutrina em sua grande parte continua a defender a inclusão das EFPC como entidades assistenciais, para fins da imunidade do art. 150, VI, 'c'. Propugna a aplicação dos requisitos do artigo 14 do Código Tributário Nacional como suficientes à caracterização para fins imunitórios. A aplicação dos artigos $203 \mathrm{e}$ 204 da CF/88 às entidades assistenciais é rechaçada, considerando-os como somente aplicáveis à assistência social pública estatal. O principal argumento utilizado é a suposta existência de dois conceitos de assistência social na CF/88: um de caráter lato, que abrangeria outras atividades como a previdência, além da própria assistência social; outro conceito de assistência 'stricto sensu', referente especificamente à assistência social estatal, que seria o presente nos artigos 203 e 204 da CF/88. Nesse sentido, é citado o artigo 149, $\S 1^{\circ}$ da CF/88 (em sua redação original, anterior à EC № 41, de 19/12/2003) como indício da existência na $\mathrm{CF} / 88$ do conceito de assistência social lato sensu.

6- As críticas que podem ser feitas ao raciocínio supra exposto inicialmente sustentam-se na indubitável diferenciação que a $\mathrm{CF} / 88$ realizou entre os campos da assistência e previdência, e na regulação específica da assistência social, prevendo-se inclusive a colaboração entre $\circ$ Estado e as entidades assistenciais e beneficentes, através do art. 204. O intérprete na análise do art. 150, VI, 'c', não pode ignorar os parâmetros estabelecidos pela CF/88 para a assistência social, que afetam diretamente o conteúdo desse artigo. Ressalte-se a inadequação da utilização do artigo $149, \S 1^{\circ}$ pelo fato do artigo tratar de regime próprio de previdência dos servidores públicos, o que não se confunde com plano de previdência complementar. Ademais, a nova redação do art. $149, \S 1^{\circ}$, dada pela $E C$ no 41/03, retirou do artigo a referência à assistência e a nova redação trata somente de regime previdenciário. 
7- Quanto à jurisprudência do STF, historicamente ela tem oscilado em termos de exigência dos requisitos e de seu conteúdo. Basicamente, as discussões estabelecem-se em torno dos seguintes requisitos: a) fim público institucional, b) gratuidade e ausência de fins lucrativos e c) generalidade na prestação dos serviços ou na distribuição das utilidades. A interpretação sobre o conteúdo desses requisitos variou muito no decorrer do tempo, e tratando especificamente da gratuidade, especialmente relevante para o caso analisado, a jurisprudência oscilou entre a exigência ou não de uma gratuidade absoluta, embora tenha-se apresentado uma forte tendência a desconsiderá-la, considerando como relevante somente a não- distribuição dos lucros.

8- Esse quadro sofreu uma interessante modificação na questão específica da EFPC a partir do julgamento do RE 202.700-6/DF - o caso CERES (data do acórdão: 08/11/2001). Em julgamento pelo Pleno do Egrégio Tribunal, definiu-se pela negativa da imunidade à referida entidade, baseando-se principalmente na ausência do requisito de gratuidade das prestações aos beneficiários, existindo a vinculação entre o fornecimento de prestações e benefícios aos participantes unicamente mediante contribuição destes. Posteriormente, o STF aparentemente muda seu posicionamento, ao julgar o RE 259.756/ RJ - o caso CONSHELL (data do acórdão: 28/11/2001), no qual concedeu a imunidade à entidade, reconhecendo-a como assistencial. Entretanto, ao analisar o referido acórdão, observa-se que a motivação para a decisão foi a gratuidade das prestações aos beneficiários, ou seja, a inexistência de contraprestação por parte desses e assunção de todo o ônus pela mantenedora). Portanto, o Pleno do STF estabeleceu dois grandes paradigmas no tratamento das EFPC: as entidades que exigem contraprestação de seus beneficiários não se enquadram como entidades assistenciais, para fins da imunidade do art. 150, VI, 'c' (caso CERES); como exceção, permanecem como assistenciais as entidades cujo custeio é totalmente coberto pela instituidora, sendo as prestações gratuitas para os beneficiários (caso CONSHELL). Esse entendimento consolidou-se na edição da Súmula 730, em 26/11/2003, cujo enunciado é o seguinte: "A imunidade tributária conferida a instituições de assistência social sem fins lucrativos pelo art. 150, VI, c, da Constituição, somente alcança as entidades fechadas de previdência social privada se não houver contribuição dos beneficiários." 
9- Desta forma, a imunidade tributária conferida a instituições de assistência social sem fins lucrativos pelo art. 150, VI, c, da Constituição, somente alcança as entidades fechadas de previdência social privada se não houver contribuição dos beneficiários. A maioria das Entidades Fechadas de Previdência Complementar, que efetivamente recebem contribuição dos beneficiários, não poderão mais ser enquadradas como assistenciais, não obtendo o enquadramento na referida imunidade tributária.

\section{Bibliografia:}

DERZI, Mizabel. Comentários a BALEEIRO, Aliomar. Limitação Constitucionais ao Poder de Tributar, $7^{\text {a }}$ ed, Rio de Janeiro: Forense, 1999, p. 324

FERREIRA, Odim Brandão. A Imunidade Tributária das Entidades de Previdência Fechada - Uma análise sob a perspectiva da Metodologia Jurídica. Porto Alegre: Sergio Antonio Fabris, 2001.

.Imunidade Tributária das Entidades de Previdência Fechada, In: Revista dos Tribunais: Cadernos de Direito Tributário e Finanças Públicas. São Paulo: Revista dos Tribunais, 1995. Abril-junho 1995, N. 11

MARTINEZ, Wladimir Novaes. Curso de Direito Previdenciário. Tomo IV: Previdência Complementar. 2. ed. São Paulo, SP : LTR , 2002

MARTINS, Ives Gandra. Imunidade de Instituições sem Fins Lucrativos Dedicadas à Previdência e Assistência Social. In: Revista Dialética de Direito Tributário. São Paulo: Dialética, 2003. N. 94. P. 64-78.

RODRIGUES, Flávio Martins. Fundos de Pensão: temas jurídicos. Rio de Janeiro: Renovar, 2003.

TEIXEIRA, Maria Isabel Dutra de Castro. Entidades Fechadas de Previdência Privada e a Imunidade Tributária. (Estudo da Secretaria da Receita Federal ) Disponível em: http://www.receita.fazenda.gov.br/srf.www/historico/esttributarios/direitotributario/entidade sfechadas.htm . Acesso em 30/05/2003.

\section{Acórdãos analisados:}

BRASIL. Supremo Tribunal Federal. Recurso Extraordinário no 202.700-6/DF Recorrente: Distrito Federal Recorrido: CERES - Fundação de Seguridade Social dos Sistemas Embrapa e Embrater Órgão julgador: Tribunal Pleno Relator: Min. Maurício Corrêa. Data do acórdão: 08/11/2001 Disponível em: <http:// www.stf.gov.br> Acesso em 10/01/2004

BRASIL. Supremo Tribunal Federal. Recurso Extraordinário no 259756/RJ Recorrente: União Federal Recorrida.: COMSHELL- Sociedade de Previdência Privada Órgão 
Julgador: Tribunal Pleno Relator(a): Min. Marco Aurélio Data do acórdão: 28/11/2001 Disponível em: <http:// www.stf.gov.br> Acesso em 10/01/2004 